\title{
Integrating Technology for Teaching English Writing as A Foreign Language in Indonesian Context
}

\author{
Irma Savitri Sadikin ${ }^{1}$, Rini Handayani ${ }^{2}$ \\ \{savitrisadikin@ikipsiliwangi.ac.id ${ }^{1}$, englishedu18@gmail.com² \\ IKIP Siliwangi Bandung, Indonesia
}

\begin{abstract}
English writing is considered as one of difficult skills in language learning. Therefore, senior high school student have difficulties in figuring out the ideas and ways to write effectively. The aim of this study is find out the effect of integrating technology to the students' writing skills. This present study used a classroom action research in three cycles in twelve meetings with 35 first grade students as the participant at SMA Kartika XIX Bandung, Indonesia. The procedure of the research consisted of planning, action, observing, and reflection. The data collecting instruments were test, observation, and interview. The result of the study shows that there is a significant improvement in students' writing skill. It can be inferred that most of students understood and felt more confident in writing descriptive. The results also indicated that they were enthusiastic and motivated during the lesson by integrating technology in language learning.
\end{abstract}

Keywords: integrating, technology, writing, foreign language.

\section{Introduction}

In Indonesia, English is learnt as a foreign language. Based on 2013 Curriculum, English is one of subjects which needs. It has to be taught in Junior High School and Senior High School. In Indonesia, writing is one of language skills which has been uneasy to be learnt. This is not only because they are not able to express their ideas easily but also the students need to have a good knowledge of vocabulary, grammar, organization, etc. Students have to collaborate the linguistics elements, such as vocabulary, grammar, mechanic, organization, and content in writing. The students difficulties are possibly from academic background and personal interest of the writer to various psychological, linguistic and cognitive phenomena.

Senior High School students in Indonesia have to master twelve genres. They are descriptive, recount. narrative, procedure, explanation, discussion, exposition, news item, Information report, anecdote and review. This study is focused on descriptive text. A descriptive text is a text which describes a particular thing/object, place, or person. The students wrote about person. They should include several information about the person, such as someone's personal life, appearances, and personal qualities in their writing.

Student- centered instruction is very important in teaching writing. There are three factors to enhance students' writing: 1) asking students to write often, in meaningful contexts, 2) providing frequent feedback on work in progress, and 3) requiring numerous revisions based on that feedback[1]. In recent decades, integrating technology in teaching has grown substantially, particularly in general education. Therefore, it is necessary to apply technology in 21 st century learning, particularly in teaching writing. High school students are more equipped with technology thus the characteristics and learning are obviously effect the way of learning. The 
typical Gen Z or digital natives live and breathe with technology. The characteristic of Gen Z are tech savvy, social, multitasking, and speedy in learning. Gen Z flexibility to learn in the way that works best for the learners[2]. They need options to choose from, so learning can be personalized. This makes them more reflective and independent learners than other generations. So that the aim of this study is to figure out if the integrating technology could enhance students' writing descriptive text.

\section{LITERATURE REVIEW}

\subsection{Overview technology in learning}

The recent innovation in the area of language teaching and learning are related to computer and followed by the invention of the internet with the World Wide Web. In this early part of $21^{\text {st }}$ Century the range of technologies available for use in language learning and teaching has been very diverse and the ways that they are being used in classrooms all over the world. This influences the essential of using technology in language classroom has become popular. Some reasons of implementing technology or ICT in language learning: 1) internet can be accessed easily anytime and anywhere by the learners; 2) younger learners are growing up with technology. And it becomes part of their life; 3) English language is being used in technologically mediated context; 4) The internet provides many resources for supplementary teaching materials; 5) The internet could create collaborative and communicative learning among learners; 6) course book materials can be given in ICT context;7) Learners expect to involve IICT in their language learning; 8) Technology provides new atmospheres for language learning and assessing language; 9) Technology can be accessed anytime and anywhere; 10) use arrange of ICT tools can give learners exposure to and practice in all of the four language major skills (reading, writing, listening, and speaking)[3].

The integration of ICT changes the system from teacher-centered teaching and learning model to an autonomous learning model which provide students' critical thinking and creativity. Students' skill will increase through technology based learning. The students can make the materials meaningful to them since the use of technology could possibly force them to be active[4]. ICT could bring in contact with native speakers and their cultures so that it helps students to become more confident and proficient in their learning[5]

The aim of Learner-centered and autonomous learning is to encourage learners to construct and engage new knowledge independently and solve problem [6], [7], [8]. In this study, the students were given opportunities to control their own learning by exploring writing aspects, such as, mechanic, vocabulary, grammar, content, and organization of the text. Most of the learning was presented online so that the learners explore the activities meaningfully through the sites.

\subsection{The Use of Technology in Writing}

The source on web which is originally called WWW is an important source of information for teaching writing. There are several factors related to the principles of online learning, particularly in teaching writing: first, the accessible textual resources may be required for students. Accessible resources play an important aspect to meet the learners' need in getting information [9]. They mention the students could cope with the text when they use clear type of 
font and space the letter so they will achieve the maximum accessibility. Second aspect is visual images which provide combination between images and text [10],[11]. Third is from the organizational structure. So that, the use of websites or external sites enables the learners to travel from one page to the next at the click of button. It can be inferred that external links on page is important to provide more information and the learners are safely controlled by the teacher when explore other sites. Today's digital students think of information and communications technology (ICT) as the integral part of their social life. Because they use technology to acknowledge each other and form their personal identities [12].

\section{Method}

In this study the researcher used classroom action research. The Action research is conducted by teacher researchers, principals, school counselors, or other stakeholders in the teaching learning situation, to collect information about the ways that the researchers could control how he/she teaches, and how well his/her students learn. The researcher has to be able to identify a problem found in the classroom before implementing classroom action research[13]. So that, good collaboration between researcher, teacher, students, and the stakeholders occurred to achieve students' better performance. In the procedure of the research, there is a planning stage then followed by action, observation and the final stages is reflection(Figure 1).

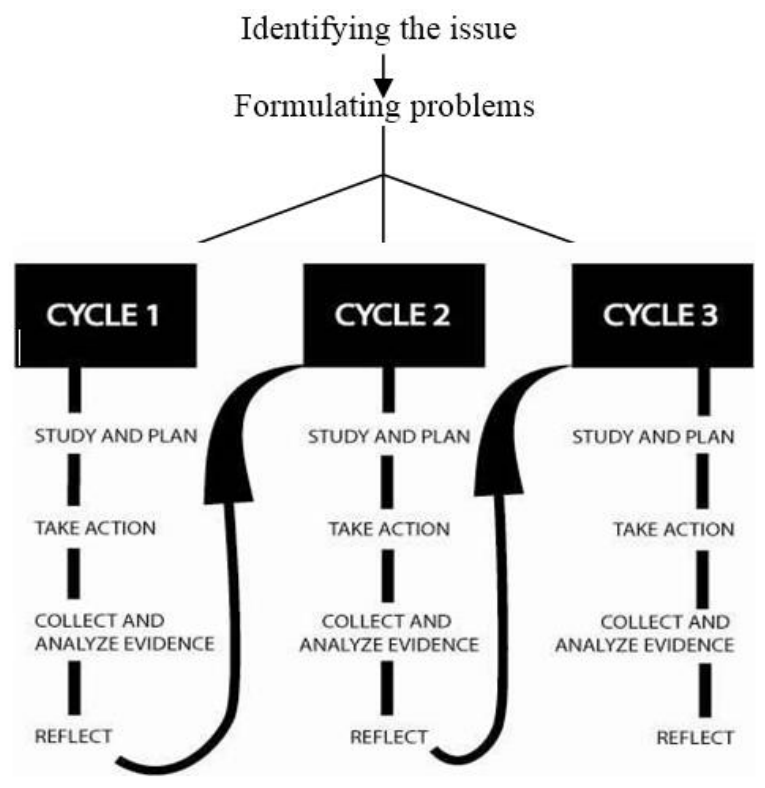

Fig.1. the Conceptual Framework of Action Research

The qualitative data is analyzed using descriptive interpretative technique. This study follows three steps in analyzing data. First, the data were selected, focused, and summarized from field notes. In this step the researcher selected, limited, and summarized the data from the implementation technology in teaching writing. Second, the data is described narratively. The 
description of the data was in the form of sentences and table to interpret the data comprehensively. Third step, the researcher drew conclusion and provided suggestion based on the data analysis.

\subsection{Participants and Setting}

The research subject was conducted at SMA Kartika XIX-1 West Java. The subject of this research was the students of class X MIA 4 that consisted of 35 students in academic year of 2018/2019. The time allotment for this research is about 3 months, from July 208 to September 2018. It includes pre-research (class observation and interview) and each cycle involved planning, acting, observing, and reflecting.

\subsection{Reserch Instrument}

The instrument used in this research were: Indonesian latest Curriculum (K-13). Discovery learning and web-based learning techniques were applied to integrate technology in learning descriptive text. Students' skill in writing descriptive text were measured using a writing assessment rubric[14], there are five aspect that can be used to assess writing, such as content, organization, grammar, vocabulary, and mechanic. Each of these assessment aspects has assessment score 1-4. Thus, students can get maximum score 20 and minimum score 5

\subsection{Action Research}

As stated earlier that action research occurs through a process, which consists of four important stages. The stages are planning, action, observation, and reflection [15]. The action was done in three cycles that consist twelve meetings (Figure 2).

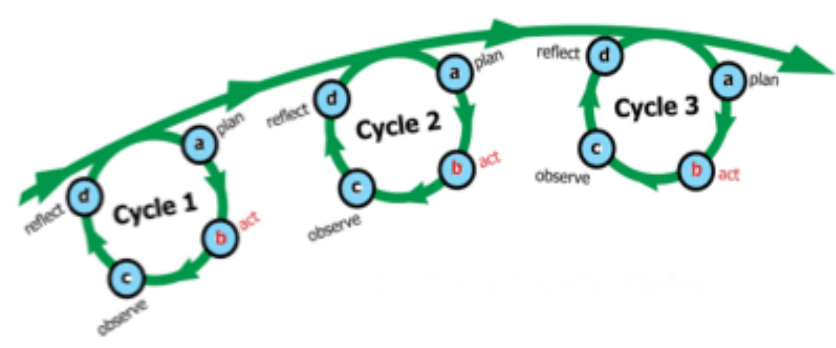

Fig.2. Steps of Action Research

\section{Result and Discussion}

The instrument used in this research was Indonesian latest curriculum (2013 Curriculum) and the instruction of the lesson used discovery-based learning and web-based learning. This research consists of three cycles. In the first cycle of the first treatment, the teaching process did not use discovery based-learning and web-based learning. The use of these two techniques was applied in the second and third cycle.

\subsection{The Implementation in Cycle I}


In cycle I, the teaching process did not integrate technology in the classroom. During the lesson, the students seemed bored and unenthusiastic in learning. Some of the students were having a chat with their peers while the teachers explained the lesson on descriptive text. The class was quite noisy and disorganized when the students were asked to discuss and create a descriptive text in pair. Based on the observation, they were not able to explore the ideas in writing descriptive. It is found that almost all writing aspects (content, vocabulary, grammar, organization, and mechanics) were low. This happened due to the teacher-centered and monotonous teaching practice. In addition, the school facilities were not used optimally, such as overhead projector, language laboratory, and teaching media. So that the students were not motivated and engaged to the process of learning. basically has to do with students' eagerness and willingness to be active in the learning process. Motivation has to be seen from selection attention to the division of motivation within the educational field as to whether motivation is a primarily a cause or an effect of learning[16]. Classroom practitioners need to be able to develop their teaching practices to create high students' motivation in language learning .

\subsection{The Implementation in Cycle 2}

Cycle two consists of three meetings. Students started learning descriptive text by integrating several applications in their learning. They learnt about how to describe personal qualities and physical appearance. The material was delivered by accessing padlet app (www.padlet.com). In cycle two the students studied a variety of vocabulary in their personal qualities and physical appearance accompanied by several quizzes from www.quizcreator.com. The students worked on it in groups. They had to answer questions and competed with other groups. This activity was very interesting and fun because it could help them in remembering vocabulary and making the structure of English sentences correctly. After the quiz ended, the teacher asks students to prepare a photo of one of their families that they have stored on their handphone/ipad /tablet. Students were asked to describe one of their family members by raising aspects of personal quality and physical appearance in the paragraph. At the following meetings, they were asked to make a paragraph about one of their idols. They wrote paragraphs on the padlet app. During this activity only a few students still ask about the order of adjectives material. Most of them have started to apply the linguistic elements that had been studied quite well.

Based on the findings in the reflection stage whare was carried out gradually and repeatedly, some students were still not confident in arranging sentences correctly in the paragraph. They kept asking the researcher to make sure that what was being wriiten was appropriate. However, the students' motivation increased and they participated actively during the learning process. Moreover, they were very enthusiastic in doing the exercises and writing descriptive paragraph through the applications. on the evaluation value in this cycle, the average is still less than $70 \%$ . The writing aspect that still needs to be improved in this cycle is from the aspect of vocabulary and and grammar.

\subsection{The Implementation in Cycle 3}

In this cycle, as many as 3 learning meetings, students learned through online resources both individually and in groups. Learning was done by using personal laptops of students and students working on the computer lab because learning was done online. These teaching and learning resources and are immediately followed by a short quiz, and students can assess their own understanding. In addition, students also worked in groups analyzing sentence errors in the 
text. During the activity they analyzed and constructed sentences well and correctly. Web-based learning gave a very good impact on aspects of writing assessment. Indicators of achievement in aspects of writing descriptive text are aspects of Content, Grammar, Vocabuary, and Mechanic[14]. In this cycle, the improvement was found in all aspects of writing. Students are much more mature in writing text using the language element in context. Based on evaluation that have been carried out in the third cycle, it can be found that students who reach $90-95$ is $17.14 \%$, the value of $80-85$ is $71.42 \%$ and the standard value of KKM 75 is $5.71 \%$. Then the third cycle is considered to have been completed.

The result of teaching descriptive text by integrating technology in the classroom in cycle I, II, and III is clearly illustrated in Figure 3. The score on the writing aspects in cycle I was quite low. This is because students did not use technology in the process of learning. Therefore, they were unmotivated, lack of vocabulary, and unable to develop their writing ideas. The improvement of students writing descriptive text can be found in cycle II and cycle III. The score improved in cycle III which is twice as higher than in cycle I of several writing aspects. This result shows that the use of learning applications could help their ability in writing descriptive text. During the learning, students got a lot of information from the websites which developed their writing ideas. Besides, the researcher often mixed students to work in group. This was aimed to let the students help and support each other. Based on the observation, it can be found that the students could work cooperatively and showed high solidarity when they worked in the group. Learning environments such as applications or social media in learning enhance interaction and communicative practices among learners[17],[18].

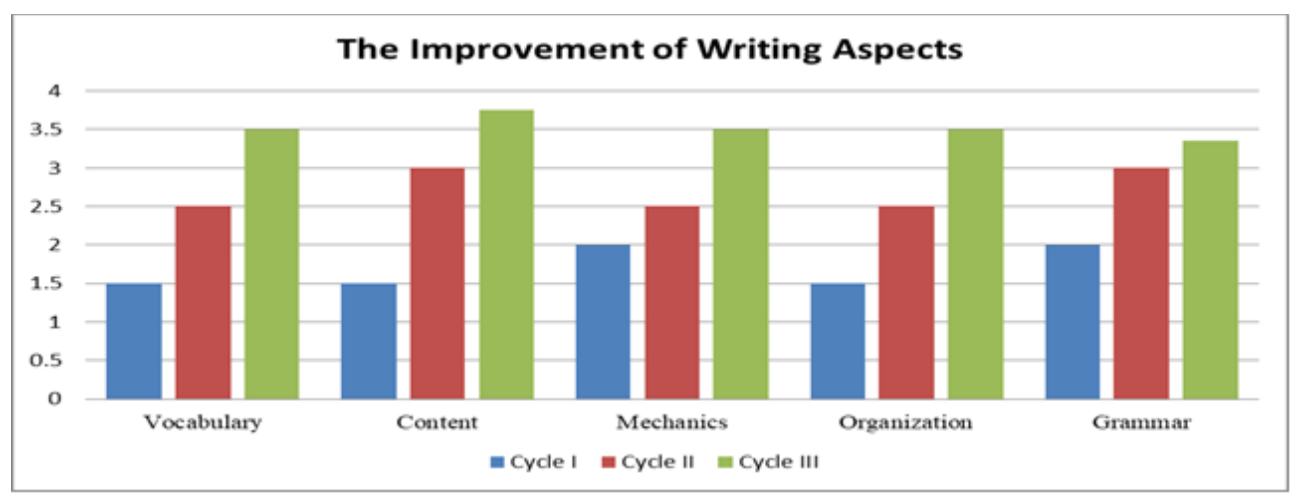

Fig.3. The Improvement of Writing Aspects

The content aspect of writing in cycle I showed that it was only a half of the good criteria. Its improvement in cycle III was higher than other aspects. The other aspects of wring such as vocabulary, organization, mechanic, and grammar showed in a very good progress of the students' writing descriptive text. These findings are in line with the constructivist theories which provide a framework in a digital age[6]. online learning activities encourage learners to construct and engage new knowledge independently and solve problems[6],[8]. Besides, integrating technology in the classroom as one of online learning capture some advantages for learning [19],[20],[21], for this reason the result shows that the learners learned descriptive writing through applications are better than conventional technique.

Figure 4 shows that the average in cycle I was $52 \%$. This is because the students did not fully utilize technology and learning applications. At the beginning of the meeting, students got the material by using conventional approach in learning descriptive texts and the learning 
process was teacher-centered. In cycle II reached $68 \%$. This is because students learned descriptive text by integrating technology in learning. In cycle III. There was significant improvement as the average score reached $82 \%$. The classroom becomes a "virtual learning environment." Learning is no longer bound by space and time. Emerging from the synthesis of the engagement of online learning to language learners, online learning could enhance students' self-belief, creating an active and collaborative learning which fosters learning relationship, and help the learners to find the information they want in English learning when such information is not available in the classroom[22], [23]. In addition, the role of teacher is crucial to encourage learners' learning. Online learning has enormous amount of interactive content, some of which is highly exploitable in the classroom. It can be inferred that the difference in the average score of cycle I and cycle III, there was an increase of $30 \%$. Therefore, the writing descriptive text of the tenth grade students at Senior High School in Bandung improved.

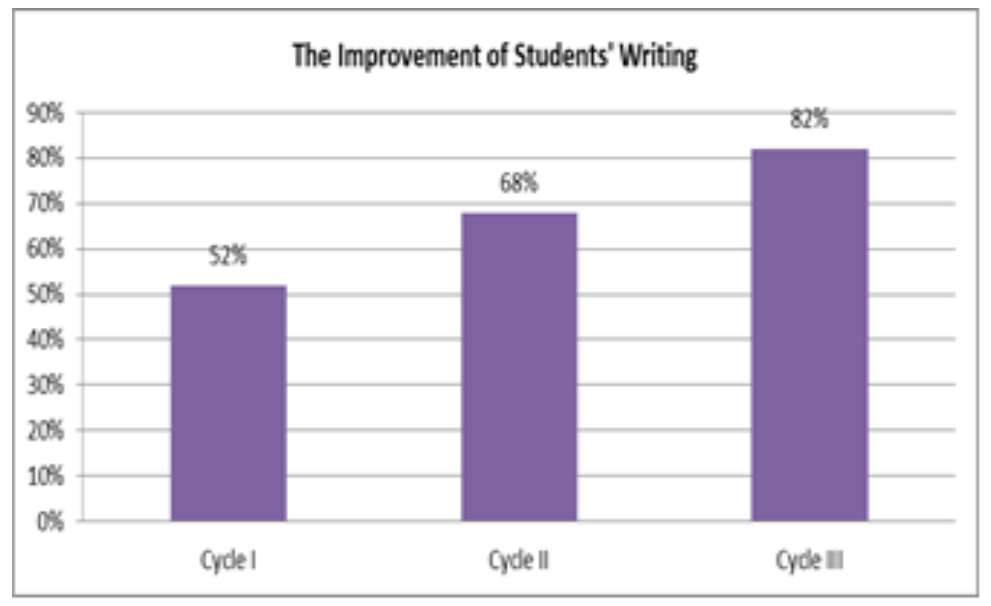

Fig.4. The Improvement of Students' Writing

\section{Conclusion}

The result of this study shows that the integration of technology in learning plays an important role in learning English, especially learning descriptive texts for 10th grade high school students. This was supported by data that there was an increase in each cycle. In cycle I students did not maximally studied descriptive text. They lack in developing English ideas, numerous grammatical inaccuracies, Very poor knowledge of words, word forms, and not understandable, and it is dominated by errors of spelling, punctuation, and capitalization. Based on the reflection in cycle I, the score of all writing aspects improved in cycle III. The improvement of students' performance in writing descriptive text can be found from: 1) effective choice of words and word forms; 2) few grammatical inaccuracies but not effect on meaning; 3) description are arranged with almost proper connectives; 4) the topic is complete and clear and the details are related to topic; 5) occasional errors of spelling, punctuation, and capitalization.

Teachers can modify several of materials from sites to support a variety of activities in the classroom to help fulfill their teaching goals. A lot of materials from internet can be specifically downloaded to support an existing topic from the course book. Furthermore, the Internet has 
swamped the students with information about anything and everything. It comes naturally to the learners because they have lived with it for their whole lives. The learners of generation $\mathrm{Z}$ are motivated, active, researcher, smart-minded, and extremely technology savvy [24]. Therefore, it is a challenge to develop their talent to engage and support them so that they stay productive[25]. Consequently, teachers have to truly understand technology and keep up with the Gen $\mathrm{Z}$ because they will expect to use technology in their classroom.

\section{Acknowledgments.}

This work would not have been possible without the financial support of Ministry of Research and Technology in PDS grant program. The researches are thankful to and fortunate enough to get constant encouragement, support and guidance from Rector of IKIP Siliwangi Bandung, the chief executive of the PDS grant program and the principle and English teachers of SMA Kartika XIX-1 Bandung which successfully helped completing this research.

\section{References}

[1]Jati, A. Gumawang. (2017). Innovation in ELT (BMP). Tangerang Selatan: Universitas Terbuka.

[2]Rothman Ph.D., D. (n.d.). A tsunami of learners called generation Z. Retrieved from http://mdle.net/Journal/A_Tsunami_of_Learners_Called_Generation_Z.pdf

[3]Dudeney, G., \& Hockly, N. (2007). How to Teach English with Technology. Harlow: Longman.

[4]Cabero. J. (2001). Educational Technology. Design and Use of Media in Education. Cambridge, Polity Press

[5]Passey, D and Rogers, C Machell, J and McHugh, G. (2004). The motivational Effect of ICT on Pupils. England. DfES/University of Lancaster.

[6]Koohang, A., Riley, L., Smith, T., \& Schreurs, J. (2009). E-Learning and Constructivism : From Theory to Application E-Learning and E-Learning Design What is Constructivism? Elearning, 5, 91-109. https://doi.org/10.1017/CBO9781107415324.004

[7]Olson, J., Codde, J., DeMaagd, K., Tarkleson, E., Sinclair, J., Yook, S., \& Egidio, R. (2011). An Analysis of e-Learning Impacts \& Best Practices in Developing Countries. Michigan State University, 53. Retrieved from http://cas.msu.edu/wpcontent/uploads/2013/09/E-Learning-White-Paper_oct-2011.pdf

[8]Alzaghoul, A. F. (2012). The Implication of the Learning Theories on Implementing elearning Courses. The Research Bulletin of Jordan ACM, 11(11), 27-30.

[9]Nakilcioglu, I. H. (2013). The Effects of Font Type Choosing on Visual Perception and Visual Communication. Online Journal of Art and Design, 1(3).

[10]Gray, C., \& Mcblain, S. (2012). Learning Theories in Childhood. SAGE Publication. [11]Sieber E. \& Hatcher S. (2012). Teaching with Objects and Photographs" Second edition. Trustees of Indiana University Mathers Museum of World Cultures University 601 E. 8th St. Bloomington, IN 47408 Exhibit Halls: 416 N. Indiana (812) 855-6873.

[12]Fleming, L. and Sorenson, O. (2004), Science as a map in technological search. Strat. Mgmt. J., 25: 909-928. doi:10.1002/smj.384

[13]Arikunto, S. (2015). Dasar-Dasar Evaluasi Pendidikan. Ed.2, Cet.4. Jakarta: Bumi Aksara.

[14]Brown, H. Douglas. (2001). Teaching by Principle and Interactive Approach to language pedagogy. New York: Longman Inc. 
[15]Burns. Anne. (2010). Doing Action Research in English Language Teaching. New York: Routledge.

[16]Dörnyei, Z., \& Ushioda, E. (2013). Teaching and researching motivation. (2nd ed.). Harlow, England: Pearson Education

[17]Tratjemberg and Yiakoumetti. (2011).Weblogs: a tool for EFL interaction, expression, and self-evaluation. ELT Journal vol 65/4. Oxford University Press.

[18]Thorne, S. L., \& Payne, J. S. (2005). Evolutionary Trajectories, Internet-mediated Expression, and Language Education. CALICO Journal, 22(3): 371-397.

[19]Chen, R. T.-H. (2015). L2 Blogging: Who Thrives and Who Does Not? Language Learning \& Technology, 19(192), 177-196.

[20]Fessakis G., Dimitracopoulou A., \& Tatsis K. (2008). Supporting "learning by design" activities using group blogs. Journal of Educational Technology and Society, 11(4), 199-212 [21]Metaferia, T. F. (2012). Using blogs to promote reflective language learning. Journal of Languages and Culture, 3(3), 52-55. https://doi.org/10.5897/JLC12.011

[22]Zepke, N., \& Leach, L. (2010). Improving student engagement: Ten proposals for action. Active Learning in Higher Education, 11(3), 167-177. https://doi.org/10.1177/1469787410379680

[23]Kargiban, Z. a, \& Kaffash, H. R. (2011). The Effect of E-learning on Foreign Language Students Using the Student's Attitude. Middle-East Journal of Scientific Research, 10(3), 398-402. Retrieved from http://www.idosi.org/mejsr/mejsr10(3)11/16.pdf\%5Cnpapers3://publication/uuid/5D18DB6 B-11BE-4DDB-A179-045B62666C35

[24]Singh, A. (2014). Challenges and Issues of Generation Z, IOSR Journal of Business and Management (IOSR-JBM), 16 (7). 59-63.

[25]Gargi, K., and Maitri, M. (2015). Gen Z-Children of digital revolution transforming social landscape, Am. Int. J. Res. Humanit. Arts Soc. Sci. 10(3)206-208. 